\title{
A Learning and Improvement Model in Entrepreneurial Leadership
}

\author{
${ }^{1}$ Ashfaq Ahmed, ${ }^{2}$ Dr. Muhammad Ramzan \\ ${ }^{1}$ The Superior College, Gulberg 3, Kalama Chowk, Lahore, Pakistan. \\ ${ }^{2}$ Lahore University of Management Sciences (LUMS) Lahore, Pakistan.
}

\begin{abstract}
Currently entrepreneurial leadership has expended and increased momentum as developingmodel of both in research and practice. Though, there is not sufficient knowledgeon the theoretical and intangible basis of this emerging area of analysisandlot of questions are raised up on how to grow entrepreneur leadershipabilities, capabilitiesprecisely in university students. The basicmotive of thistheoretical paper is to slight the gap through offering the theoretical andconceptual basics of entrepreneur leadership. This paper has also examinedvariousfeatures of entrepreneurial education in the perspective of universitygiven entrepreneurship programs and then projected a model for entrepreneurial-leadership enlargement. The projected model describes entrepreneurial leadershipenlargementbase on a dynamic progression of "experimental, social interactive,observational and reflective learning" which make available a base for entrepreneur leadership exercise, enlightenment and research.
\end{abstract}

Keywords: entrepreneurial leadership, leadershipgrowth, entrepreneurial knowledge,entrepreneurial capabilities, learning model

\section{Introduction}

Entrepreneurial leadership as a new model of review has newly been the emphasisof research, practice and training in both entrepreneur and leadership disciplines. This isdue to the serious role that leadership abilities and capabilities of entrepreneurs show inenhance individual, group, and new effort of performance,performing, success and themomentouseffects of leaders' entrepreneurabilities and competences in dealing with highlypassionate and competitive environment of present organizations (Cogliser andBrigham 2004; D'Intino et al. 2007; Fernald et al. 2005; Frey, 2010; Gupta et al.2004; Kuratko and Hornsby 1999; Swiercz and Lydon 2002; Yang 2008).Hence, an growingresearch focused on discovering theleadershiproles of entrepreneurs as well as entrepreneurial functions oforganizational leader-ship based on the mutual threads and connectionsamongentrepreneur and leader-ship (Cogliser and Brigham 2004; Vecchio2003).However, there is limitedinformation and knowledge about the theoretic and conceptual basicsof entrepreneur leader-ship. More prominently, our informationon how togrow entrepreneurial leader-ship abilities and capabilitiesexactly in university students aspotentially entrepreneur leader-shipeither in their own undertakings or in wellknownorganizations islimited. This conceptual study put efforts to fine the gap inliterature on theoretical and conceptual basis of entrepreneurialleadership and ancombinedmethod to entrepreneurial leadership capabilitiesdevelopment (Lans and Mulder 2009). In the purpose of university entrepreneurship program and thensuggests a model for entrepreneurial leadership growth based on a vibrantviewpoint of entrepreneurial education. The model which has proposed has presents entrepreneurialleadership developments as a process of experience, social collaboration, observations, reflect learning which offers a suitablebase for entrepreneurialleadership leaning, exploration, research and exercise.

\section{Objective of the Study}

- To study the link between entrepreneurship and leadership

- To present a model of learning and improvement in entrepreneurial leadership

\section{Entrepreneurship and leadership}

Anevaluation of entrepreneurship and leadership regarding literature exposes the same process ofmodeldevelopment in both schools of believes. This process of pastdevelopmentinitiateswith aemphasis on the inborn and exceptional features of effective leaders andentrepreneurs in 'mannerisms' theories and the properties of followers and related factors onwalking into entrepreneur-ship and leader-ship actions in later concepts. In among thetwo ends, there are lotmodels which effort to give a clearimage that whatleaders and entrepreneurs do to putimpacton a group of people to enact their idea (Guptaet al. 2004; Murphy and Ensher 2008; Yukl 1998). Contradiction in research resultsrecently bound scholars of both arenas to change from behaviors and situational aspects to avibrant learning procedure through which entrepreneurs and leaders include in anevolutionary procedure (Kempster and Cope 2010) and deliberatelygrow their personaland 
practicalcompetencesand qualities in order to face the challenge of the presentoccupational world(Cope and Watts 2000; Cope 2005; 2003; Kempster 2006; Rae and Carswell 2000; Rae2000; 2006; Swiercz and Lydon 2002; Young and Sexton 2003).

On the separately individual level, leaders and entrepreneur also have many communalabilities such as innovative, proclivity to take threats, risks and have ability to imagine abetter future for the occupation and organization (Fernald et al. 2005). Resemblancesamong the both disciplines are to much that specific scholars clear entrepreneurshipas a kind of leadership and recognizedutmost of the entrepreneurs' actions asleadership actions, however in a specificeconomic and multifaceted context(Cogliser and Brigham 2004; Fernald et al.

2005; Vecchio2003). Focused onthe variancesamong entrepreneurship and leadership, further researchers called thismeaning of entrepreneurship as basic and 'parsimonious' (Vecchio 2003). Subsequentlyan entrepreneur is more than just a leader who does in an proveninstitute or organization, (s)he begins a firm or organization in the first scratched, faces different kind challenges, threats andcrises (Gupta et al. 2004) and leads in an extraordinary, strange difficultycondition (Cogliserand Brigham 2004). Furthermore, entrepreneurs are extra complex in character,traits and skills because they needed to play different roles and in different conditionsat the same time(Mattare 2008). So, entrepreneurial leaders are needed to develop extraexactcapabilities to be able to successfully develop and create a new project and bring it to successand development for the insightful goals and targets (Gupta et al. 2004; Swiercz and Lydon 2002). Regardless of all the discussions on resemblances and differences among entrepreneurshipand leadership, it is very difficult and crucial to discoverthat how the both disciplines can support thegrowth of model, project and practice in each arena, mostly, how the procedure ofmodelgrowth in leadership as the extrarecognized discipline can notifymodelgrowth in entrepreneurship as aadditionaldevelopingarena (Cogliser andBrigham 2004; Vecchio 2003). In terms of run-throughgrowth, entrepreneurs cantake benefit of leadership capabilities to handle with the manytasks ofnew projectmaking and thusupsurge the chance of their achievement in theoccupational and business world. Leaders can benefit from entrepreneurial capabilities to contractwith the highly stormy and good environment of presentgroups or organnizations(Cogliser and Brigham 2004). All the theoretically and conceptuallyoverlaysamongentrepreneurship and leadership bring scholars to combine them into a new paradigm or modelof'entrepreneurial leadership'. The interactionlinked with 'entrepreneurial leadership are not only force developing research and practice in these both disciplines but alsoshow novel belongings that are not clearlyseeming in either of the distinctmechanisms (Gupta et al. 2004; Yang 2008).

\section{Definition of entrepreneurial leadership, development and enlargement}

Actually, 'entrepreneurial leadership' is in its very initialphases of conceptual andtheoretical progress. Entrepreneurial leadership defined as a procedure ofleadership conducttypical from other types of leadership manners that arerequired for extremely turbulent, inspiring and reasonable environments (Guptaet al. 2004). Justrecently, exactcompetences of entrepreneurial leaders thatempower them to recognize chances, step-into a new venture formation and managewith the different kind of problem and challenges linked with entrepreneurial venturing havebeen recognized (Gupta et al. 2004; Swiercz and Lydon2002). Scholars had two keymethods to entrepreneurial leadership capabilitieswell-defined as the exactskills to perform leadership roles and responsibilities in entrepreneurial activities (Lansand Mulder 2009). First, 'work-oriented approach' that reflects entrepreneurialleadership capabilities as the necessarycharacteristics of entrepreneurial leaders toeffectively do the challenge roles and responsibilities of the leader in diversephases oftheir occupationaldevelopment and growth (Swiercz and Lydon 2002). Anassessment ofrare definitions projected for entrepreneurial leadership directs that mostlyrecognized three exact personal capabilities for entrepreneurial leadershipwithpositive attitude, innovative and risk taking (Chen 2007; Gupta et al.2004; Kuratko 2007; Surie and Ashely 2008). Second, 'socio-cultural and situatedapproach' that describes entrepreneurial leadership enlargement as a social procedure ofconstant and regularknowledge and 'becoming' that is situated in specificperspectivesand societies (Kempster and Cope 2010). It is claimed that entrepreneurialcapabilities and in specific entrepreneurial leadership can be well-educated anddeveloped in good manners (Baron and Ensly 2006; Kempster and Cope 2010; Lans et al. 2008). In thenextsections each of the personal capabilities of entrepreneurial leaders isdescribed. Then, we focus the exactpurposefulabilities that empowerentrepreneurial leaders to effectivelyperform the seriouscharacters and responsibilities of the leader inentrepreneurial venture.

\section{Innovativeness}

Innovativeness has been well-defined as the quality and ability of the entrepreneurial leader to think differently, creatively and develop to unique and valuable ideas in entrepreneurialprospect acknowledgment, utilization of resource and problem solving in differently (Chen 2007; Gupta et al. 2004; Mattare 2008; Okudan and Rzasa 2006). Innovativeness is thequality that segregates the magnates from those who need just to be independent (Kuratko 2005; Mueller and Thomas 2000; Okudan and Rzasa 2006).From Surie and Ashley's 
(2008) the point of view of entrepreneurial leader isto develop and creativeinnovative who are dedicated to achievement and value making.

\section{Pro-activeness}

Pro-activeness is being energetic to create and lead the upcomingfuture perspective instead of waiting or influenced him by others. It has very typically personality and with dynamic personality characteristic of entrepreneurial leaderwho manage and enable his own business at his own ways which is entirely on creativeness and wisdom (Fuller and Marler 2009) andimagine a very successful future for it (Hannah et al. 2008). It definitely develop and create and empower entrepreneurialleaders to furcate and anticipate in upcoming future challenges and problems, identify opportunities and classifyand identify the needsfor change and enhancement (Kuratko et al. 2007; Okudanand Rzasa 2006). The impact of proactive approach put effects in shape of success, business growth, and alignment with the line of sightwith creativeness andtarget to initiate entrepreneurial actions (Kickul and Gundry 2002;Zampetakis 2008). |From the learning perspective it needed that the proactive attitudemotivates entrepreneurs to highlight and recognize learning needs and involve in learningactions and different kind of training programs to manage with the predicted crises, challenges and barriers of theirbusiness management (Cope and Watts 2000; Major et al. 2006; Young and Sexton2003). Indeed, entrepreneurial leadership is a positive and proactive response toenvironmental opportunities (Surie and Ashley 2008).

\section{Risk taking}

Risk taking is the based on willingness of entrepreneurial leader to absorb uncertainenvironment andtake the big responsibility and challenge for the future (Chen 2007). Sensible andplanned risk taking is one of the communal characteristics of entrepreneurialleader, mostly, in the initialphases of the entrepreneurship procedure (Robinsonet al. 2006; Zhao et al. 2005). Moreover, entrepreneurial leaders are consideredas having a superiortendency to take risks than cope and they need to takedifferent risks in variousplatforms of their projectformation and growth (Muellerand Thomas 2000).

In addition,characteristics, entrepreneurial leader need to ownexactqualities to perform and play a successful role ofleaders in entrepreneurial endeavordetermined on leadership capabilities thatentrepreneurial CEOs need to create and develop in diversephases of their businesscreation, progress and growth, Swiercz and Lydon (2002) categorizedcapabilities of entrepreneurial leaders in to brillianttalentswithin individuals and operational-capabilities. The authors stressedknowledgeabletruthfulness, helpingthe company instead of single leader, developingoutsidementors andmaking a maintainableorganization as self-capabilities of entrepreneurial leaders. There ismarketing, finance and human resources (HR)are the important functionalcompetencies of entrepreneurial leaders. Still, entrepreneurship intellectualsare in research to find out more exactand specific capabilities of entrepreneurialleaderwhich make them different and advantage over the others kind of leaders.(Gupta et al. 2004).Furthermore, entrepreneurial leaders learning is arelational knowledgephasewhich there are no commonly accepted theory(Kempster and Cope 2010).

Through personal development viewpoint and base on the tasks thatentrepreneurial leader faced in organization competencies and setting where theyrequire manage with the different challenges and responsibilities, Gupta et al. (2004) establishedand developed a theoreticalbase for entrepreneurial leadership. According to the model, entrepreneurialleaders face different kind of two challenges in the development of organizational leaders. The first challenge, "Scenario enactment", is future visionary where they create innovative possibilities for future. 'Cast enactment', the second challenge, elaborate as 'influencing' and inspirational a group of able and dedicatedfollowersskillfulof achieving the purposes of the scenario. Facing such challenges, entrepreneurial leaders show two seriouspartswith 'building commitment' inthe groups, and identifyingboundaries and shouldinnovative and risk takers.

Therefore, entrepreneurial leaders has need to develop a group of personaland practicalcapabilities to be able to effectively developvision and do the challenging responsibilities and roles of entrepreneurial leaders(Kuratko 2007; Okudan and Rzasa 2006; Vecchio 2003). They need tobe involved in a selfmotivatedprocedure of learning and development (Gupta et al.2004; Swiercz and Lydon 2002). Though there has been a practice of observing atentrepreneurship as a 'learning process', a learning viewpoint to entrepreneurialleadership traing and development has currently been conducted (Kempster and Cope 2010).

\section{Entrepreneurial learning and experience}

A very solid confidence in that entrepreneurial education and learning is an action orientated phase and process that where entrepreneurhave different kind of experience and business development, management and creation of new business. In specific, entrepreneur leadership education and learning becomes through a practice and experiential phase of running a new business which entrepreneursdevelop their sympathetic and exercise of leadership in a realistic context(Kempster and Cope 2010). Almost each experiential changes 
entrepreneur'sinformation in few fields and increases their faith in that area (Minniti and Bygrave 2001). It is claimed that 'by exquisite knowledge in a positive field, aperson's collected information will cover extra ideas and become moreconsistent, thereby growing proficiency' (Holcomb et al. 2009, 171).Practice also increases entrepreneurs' creativity, business skills, systems andbusiness position (Politis 2005). Holcomb et al. (2009) recognized a model ofentrepreneurial information that organizes new learning process into two types of "direct experiential learning' and 'vicarious learning'. While 'direct experiential learning" states to the procedure of information addition from rightfeeling several features of business controlling, 'displaced learning' is theprocedure over and done with which entrepreneurs accrue information by seeing theperformances and actions of others and related outcomes. They further argued thatboth of the experiential learning procedures distress knowledge procurement and action;though, entrepreneurs tend to depend on additional on their own previous disappointment involvements instead of others failures. Kempster (2009) also proposes that entrepreneurs'leadership knowledge happen over skills of their own activities and detectingothers. The authors stressed that observational knowledge, which happens overcontact with others, not only forms entrepreneurs' considerations of leadershipbut also modifications and changing of their leadership performance and practices.

In view of that, achieve entrepreneurial venturingefficiently, except it is completed with knowledge and experience (Henry et al. 2005; Politis2005). Entrepreneurship coaches stress important and long lasting influences ofknowledge that occurs through working many tasks and responsibilities of an entrepreneuron coaching of the students' personality, functionally and on behavior entrepreneurshipcapabilities. During the first, experimental learning chances grow students' wish andaim to become an entrepreneur (Fiet 2000; Peterman and Kennedy 2003). This education programs will increase students' own awareness and their requirements for development, creativity (Fuchs et al. 2008; Harris and Gibson 2008; Matlay 2006;2005; Pittaway and Cope 2007; Smith et al. 2006). Furthermore, empirical learningimproves students' exact entrepreneurial abilities for primary their ownbusiness and effectively overwhelming the congenital tasks (Dhliwayo 2008; Pittaway and Cope 2007; Okudan andRzasa 2006; Smith et al. 2006). In result, over such actions student knowledgedisappointment, study from it and thus grow their skills to deal with more thoughtfultasks in the future (Fayolle and Gailly 2008). This experience is also increase the social interaction of the student which they will not be gets by the class rooms' (Dhliwayo 2008, 333). In conclusion, through this experience students will able to produce new meaningthat leads to different change in thinking andbehavior' (Fayolle and Gailly 2008, 580). Additionally, empirical approaches ofentrepreneurship learning and education increase getting and stresses of students forentrepreneurship packages and are extra powerful in emerging their entrepreneurial capabilities (Plaschka and Welsch 1990). As such, Fuchs et al. (2008)highlighted that students should be given the opportunity to gain as much realexperience as expected and possible. Such in real-life practices typically have ample extra lastingproperties on the students. But there are still so much gaps to develop students' entrepreneurial leadership competences (Okudan and Rzasa 2006). How to association entrepreneurship model and exercise has been single of the maximumserious matters in entrepreneurship learning.Henry et al. (2005) indicated that dynamicand empirical approaches of entrepreneurship teaching should not result inunawareness of model. Fiet (2000) also promotes with models in entrepreneur ship progressions to improve students' intellectual talents for better entrepreneurial conclusioncreation. In difference, observers on extra focused on entrepreneurshipmodels suggest the lacks of theory based methods to entrepreneurship learning in developing new creation, innovation and practical capabilities of the entrepreneurship students (Dhliwayo 2008; Heinonen and Poikkijoki 2006; Tanand Ng 2006).

\section{Entrepreneurial learning importance and process}

Recently, entrepreneurship learning has becomekey focus ofentrepreneurship research study. That is the reason to increase interest because of the solid beliefthat entrepreneurial 'competencies and particularly entrepreneurial leadership' can beeducate and developed through practice and entrepreneurship training anddevelopment programs (Kempster and Cope 2010; Lans and Mulder 2009; Lans et al.2008). Furthermore, learning plays essential roles throughin whole the process of new projectformation, from emerging the abilities to steppinginto a new venture formation(Erikson 2003) to identifyingchances and managing with the tasks andchanging aspects of the business world (Cope and Watts 2000; Fayolle and Gailly 2008;Harrison and Leitch 2005; Politis 2005). More prominently, entrepreneurs'efficiency in prominent business learning (managing people and resources) extremely determinedon their aptitude to acquire entrepreneurial information from frequentresources and diversesettings and put on the information to adjust their performancesas well as modification their business policies (Cope 2003; Murali et al. 2009; Young andSexton 2003). Really, learning has been measured as the competitive advantageover others and one of the vigorousresponsibilities of entrepreneurs (Harrison and Leitch 2005; Kempster andCope 2010). Young and Sexton (2003) determine that "the maximumdurableentrepreneurs are those who "learn how to learn" the proceduresrelated withobtainingknowledge'. 
Anywaythe stagyimportance of entrepreneurial knowledge, our infoabout the manyfeatures of this thoughtfulprocessmostly the theoreticaldescription and tools which personalities learn various entrepreneurialcapabilities are limited (Cope and Watts 2000; Cope 2003; Corbett 2005; Harrisonand Leitch 2005; Pittaway and Cope 2007; Politis 2005). More prominently, there isnot sufficientinfoaround the ways of management learning in entrepreneurialenvironments (Kempster and Cope 2010). Intellectuals have clear entrepreneurial educationover two keyviewpoints. First, learning that happenedin the new ventureestablishmentphases (Pittaway and Cope 2007, 212). Second, learning abilitiesessential for stepping into new venture making, interacting with the tasks andissuesrelated in entrepreneurial venturing, and effectively leading to the new venture(Lans et al. 2008).

Agreed that entrepreneur learning is mostly an experimentalprocedure, themost of entrepreneurial learning are based on variousfeatures ofexperiential learning ideal (Kolb 1984) together withresearch, conceptualization, image and experience (Pittaway and Cope 2007). Based on the ideal, Politis(2005) put emphasis on that entrepreneurial learning is an experimentalprocedure in whichinformationgrowsovercome into contact with, replicating, rational and act. Rae andCarswell (2000) observed at entrepreneurial learning as the reasoningprocedures ofacquisition and arranginginformation as well as giving sense to practices. Inspirit, entrepreneurial learning mentions to aenergetic and continualprocedure ofobtaining, integrating, forming and involving the new knowledge and competencieswith pre-existing structures to be retrievable for use in routine and strategic actions(Cope 2005; Holcomb et al. 2009; Minniti and Bygrave 2001; Rae and Carswell2000).

This process has three main components including experience, transformationprocess and knowledge, and enables entrepreneurs to effectively recognize andexploit entrepreneurial opportunities and deal with problems and crises of the newbusiness (Politis 2005). Learning that occurs through facing, overcoming andreflecting on problems and challenges of new venture creation and development ismore influential in enhancing entrepreneurial competencies and success or failure ofthe entrepreneurial put forward (Cope and Watts 2000; Cope 2005; 2003; Fayolle andGailly 2008; Pittaway and Cope 2007; Politis 2005). The thoughtfulinfluences oflearning overoverpoweringdifferentdifficulties and seriousactions is because ofvariety in the information and capabilitiesgathered from newtasks andproblemslikened to familiar areas (Holcomb et al. 2009). In adding further discussion to theongoing discussions on conceptual entrepreneurial education, Lans et al. (2008)criticismon entrepreneurship research work becausethe limited model foreducational entrepreneurial abilities. Based on the this discussion and observing at entrepreneurial learning capabilities from an learningview (Lans andMulder 2009; Lans et al. 2008) in the perspective of university entrepreneurprograms, the these portionsinspectvarious points of the entrepreneurialeducational phasesconsideringpractice, societalcollaboration and interactionshow its impactsto build the bases for emerging and developing a model for entrepreneurial leaderswould be development based on an combinedmethod to entrepreneurial learning and education.

\section{Entrepreneurial learning and social interaction}

In spite of the vigorous body of research study on the associationamong entrepreneurialeducation and practice, the literature on social features of entrepreneurial educationprocedure is astonishingly scarce. Though, lot of empirical research studies indicate that social interaction is very important for entrepreneurial education(Cope 2005; Man and Yu 2007; Pittaway and Cope 2007). In spirit, entrepreneuriallearning happens in a multifaceted and energeticprocedure of personal collaboration with theenvironment (Cope 2003; 2005; Rae 2007; 2000) that made a shape and develop theentrepreneurial insights, arrogances and skills(Rae and Carswell 2000). Inspecific, entrepreneurial leaderscompetencesgrow only by being involved in avibrantprocedure of contactamongindividual and relatedaspects (Holt et al.2007; Kempster and Cope 2010; Kuratko 2007; Vecchio 2003). Social collaboratinglearning allows entrepreneurs to discoverchances and manage with the disasters ofthe new business management (Corbett 2005; Heinonen and Poikkijoki 2006; Pittawayand Cope 2007). Surie and Ashley (2008) decided that by performing the numerousgroundbreakingparts and actions, entrepreneurs study entrepreneurial leadersover social connections and a procedure of socialization. Kempster (2009)highlighted that not only obtainability of societalconnectionswith'distinguished people'extremelyeffect entrepreneurs' leadership knowledge and growth but also diversityand range of social relationsmeaningfullytouch their leadership knowledge(Kempster 2009, 440).

Focused that how social connectionsgrow students' entrepreneurialknowledge, Fuchs et al. (2008) highlighted that social connectionsprogress students'own consciousness of their faintness and assets as well as their development incommunication abilities and interacting. The authors extraclarified that socialconnectionsassistance students to part and task their variousvisions andintellectualprocedures, realize weak points on their intellectual and the techniques toincrease them, exact one extra, amend their understanding on the foundation of others'considerate and, more prominently, put on the learnedinformation and abilities tosolve the difficulties. Moreover, the informationincreased as a consequence of societalconnectionsamong 
people who have variousskills and viewpoints is in alevel developed than the knowledgelearned by persons (Pittaway and Cope 2007).

Moreover, the interactionamongseparate and shared learning makesentrepreneurial knowledge more and permanent (Man and Yu 2007; Smithet al. 2006). Such societal interactive plans and programs also give social know-hows throughwhich students exerciseimportantduties that increased their wish to stepinto entrepreneurship (Peterman and Kennedy 2003). Furthermore, social communicatingincrease learning creativity and innovations which are the basicselements ofthe entire entrepreneurship procedure (Ko and Butler 2007; Rae 2006).

Entrepreneureducation plans and programs give and create so manychances for students' to societalconnectionsand interactions (Peterman and Kennedy 2003) thatgrow and develop theirentrepreneurial capabilities in overall and entrepreneurial management in specific(Vecchio 2003). This kind of programs offerchances for communicationsand interaction with lecturersand peers in the groups that is serious for the entrepreneurial knowledgedevelopment anddevelop students' friendliness on entrepreneurial actions as well as their apparentalike of entrepreneurial capabilities (Man and Yu 2007; Pittaway and Cope 2007).

Moreover, social conflicts and taskswhich make to students more experienced throughdevelopment of a new business vision with in their group to play abig role in allowing them to review their action and tactics with theirmindset and behavior for their planning (Pittaway and Cope 2007). So, it is very important to students from different background and experiences that they will get social experience and learning in entrepreneurship learning (Heinonen 2007, 319).

Entrepreneurship kind of program also provides excess to same mind of students and people facilitation. These programs also provide chances for students tobe uncovered entrepreneurs and depositors on such as training, poolmeeting and business commercewhere they have such chance and opportunities (Souitaris et al. 2007; Zhao et al. 2005).

\section{Entrepreneurial learning and reflection}

While many entrepreneurship scholarswell-defined entrepreneurial knowledge as amixture of experience and social contact(Cope 2005; 2003; Cope and Watts 2000; Pittaway and Cope 2007). For themactual entrepreneurial knowledgehappenssimply if entrepreneurs include in a procedure ofexamining and understandingempirical and theoreticinformation in differentproceduresof replication (Pittaway and Cope 2007). Actually, thoughtfulknowledge has beenmeasured as the maximumimportant learning instrument for entrepreneurs that makebasicups and downs in their awareness for cope theirbusiness efficiently (Cope 2003; Cope and Watts 2000).

Moreover, likenessmakes entrepreneurs to not only integrate, rearrange their thoughtful and developedinformation from diverseevents. They will able to increased prevent developmentto handle tasks, problems andchallenges for their business cope (Cope 2003; Cope and Watts 2000;Holcomb et al. 2009). Holcomb et al. (2009) noted that successive integration ofaccruedinformation 'more firmlyoriginal knowledge, extendsthoughtful, and enablesupcoming learning and acts' (171). This opinionhighlights the part of likeness for carryingthe collected and combining thediverseinformationattained from manysituationspreciselypractices andsocial relations (Pittaway and Cope 2007). More prominently,thoughtful learningproves the seriouspart of persons to successfully integrate and consolidate(Holcomb et al. 2009).

Cope (2005) argued that over reflection on the precedingdifficulties andtasks entrepreneurs grow a reproductiveknowledge which is reflectiveand probable, adaptive and positive. In Young and Sexton's (2003) opinion entrepreneurs involve in knowledgeactions because of their oversensitive andpositivereproduction on chances or difficulties that hamper the development andgrowth of businesses. But, for variousentrepreneurs getting knowledge through thinking is very hard because they are not use toreflect on their acts (Cope and Watts 2000). Emerging entrepreneurial capabilities of students over reflective knowledge hasonly newlyarisen in entrepreneurship learning programs. Focused on this ignoredfeature of entrepreneurshiplearning, Pittaway and Cope (2007) established a plan or programthat is called 'new ventureplanning'. This plan or program will provide various opportunities that they will develop their self.But, till now there is no any detailed and comprehensive model of entrepreneurial capabilities learning that assimilatesmanyfeatures of entrepreneurial education and learning in order to grow the exactabilities in potential entrepreneurs that allow them to effectivelyperformseriousparts and responsibilities of an entrepreneur (Lans et al. 2008).

\section{Methodology}

This is qualitative paper. This paper explores the previous work done by different researchers. This paper also throws light on entrepreneur and leadership and also their role in an organization. This paper will also help to understand the social impacts on leadership. After studying different work, author also has presented a model for entrepreneurial leadership for learning and development. 


\section{A projected model for entrepreneurial leadership enlargementestablished on acombinedmethod to entrepreneurial learning}

One of the keyapprehensions of this theoretical paper was to improve a model ofentrepreneur leadership learning and expansion for which no additional model hasbeen established yet. Draw a diagram upon the conceptual basics ofentrepreneurial leadership and energetic and combinedmethod to entrepreneurial learning (Lans and Mulder 2009), a model for entrepreneurial leadershipcapabilitiesexpansion is projected. The model signifies entrepreneurialleadership enlargement as a procedure of communication and combination of diverseapproaches of entrepreneurial learning as well as"experience, observation, social inter-action and reflection" (see Figure 1). According to the model, energetic involvement indiversekinds of entrepreneurial learning grows entrepreneurial leadershipabilitieswithskillsessential for "Scenario enactment namelyproactiveness" innovative, threatand risk taking which arecommitted and agreeingboundaries (Gupta et al. 2004; SwierczandLydon 2002). The model is founded on a completemethod to entrepreneurialleadership capabilitiesrepresentative that the abilities can be educated andestablished and are consistent (Baron and Ensly 2006; Lans and Mulder 2009). Onthe furtherpointer, executionmany leadership responsibilities and characters in entrepreneurialperspectivesgrows entrepreneurs' considerate and ability of leadership inrelative to others and their business atmosphere (Kempster and Cope 2010).Leadership performsimproveknowledge entrepreneurial abilitiesovercontinuallyobtaining new manners, emergent new ways of considerate and knowledgehow to learnas ofmanycapitals (Cope and Watts 2000). The objective foremploying an combinedmethod to entrepreneur leadership abilities andentrepreneurial learning is threefold: first, to adjust the difficulties and"multi-faceted nature of entrepreneurial leadership learning and development"(Cogliser and Brigham 2004; Kempster and Cope 2010); second, to take in bothcommonskills and exact leadership abilities of entrepreneurial leaders (Lansand Mulder 2009) and coverinter-reliant nature of entrepreneurial leadershipabilities(Gupta et al. 2004; Lans et al. 2008); third, to increase in value thestrengthening and compacting upexactof entrepreneurial educationtoolswhich have importanteffects on emerging entrepreneur leadership abilities (Pittaway and Cope 2007).

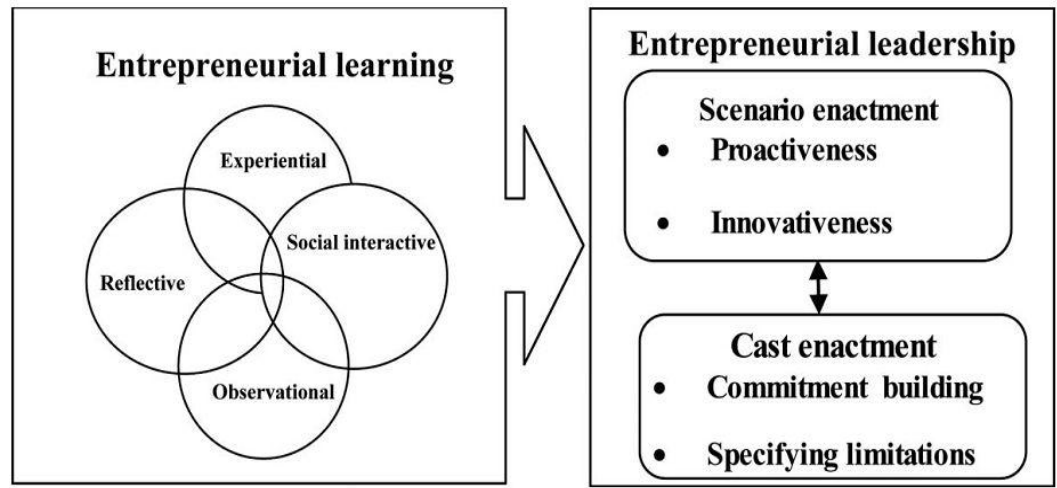

Source: AfsanehBagheri,et. al. 2011

To develop complete and perfect entrepreneur leadership qualities can be develop and learn through the process of different kind of experience and different responsibilities in various role leaders in entrepreneur activities (Gupta et al.2004; Kempster and Cope, 2010), societal interactions andcommunication with with entrepreneurial mindedpeople (Kempster and Cope 2010; Surie and Ashely 2008), are observedas real leadership exercise and practice in entrepreneurial perspectives (Holcomb et al. 2009; Kempster 2009) andreplicating on leadership performances, outcomes and entrepreneurial learnings(Cope2003; 2005; Cope and Watts 2000; Lans et al. 2008; Pittaway and Cope 2007).

Therefore, entrepreneurship coaches may need to deliver a stablechance for students in all procedures of entrepreneur leadership learning witha complete and combinedmethod to entrepreneur-ship education if they areto enhance the number and capabilities and competencies forthe future of entrepreneurial leadership.

So,entrepreneurship learners can deliver to students with projects based and actual lifeconstraints and problem solving education opportunities (Okudan and Rzasa 2006), anywhere they canknowledge the title role of an entrepreneur leader and the task and challengerelated withentrepreneur venturing, to get knowledge from numerous social connections, and reveal on theirperformance, education and learning results (Pittaway and Cope 2007). Entrepreneurshipcoaches also need to put more focus on observational-learning, the recently developingfeature of entrepreneurial-leadership development (Holcomb et al. 2009;Kempster 2009). In specific, students should be providing with thoughtful learningchances and opportunities that makes them enable to create the best practice of attainedinformation fromknowledge, experience, observation and social relations. Though, thoughtful learning is themost ignoredfeature of entrepreneurial education in entrepreneurship learningthatbe worthy of more courtesy (Cope and Watts 2000). 


\section{Conclusion and implications of the projected model}

The main purpose of the present study was to improveand develop a model for entrepreneurleadership enlargementwithstudying and making the up-to-date knowledgeon entrepreneurial leader-ship, entrepreneurial education and learning as a complex and multi-level procedure (Kempsterand Cope 2010). Agreeing tothe model, entrepreneur leader-ship enlargement is a forcefulprocedure of education and learningfrom experience, knowledge, observation, and social interaction, communication, and transforming the obtainedknowledge through a procedure and process of reflection to make out entrepreneurial chances and opportunitiesas well as makingoriginal solutions for tasks and crises of prominent entrepreneurialventures.

Through aamplemethod to entrepreneurial leadership education and learning, theprojected model can be implement in research practice development and growth forentrepreneurs as well as entrepreneur leaders in organizational setting, however itpresent entrepreneur leadership enlargement and development mostly base on entrepreneurialeducation and learning opportunities and tasksdelivered by university entrepreneurship education and learning programs.Entrepreneurs and entrepreneur leaders in well-known organizations may considerthese aspects of education andlearning as significant in their entrepreneur leadershipdevelopment and improve their entrepreneur leadership abilities throughactive participation in entrepreneur-ship education and learning (Kempster and Cope 2010).

This integrated learning method to entrepreneur leadership enlargement and development has a significant effect on shaping the mindset, attitude and behavior of entrepreneur leadership predominantly. It also specifies that all of these education and learning features and elements are serious in learning entrepreneur leadership (Cogliser and Brigham 2004; Kempster and Cope 2010).Furthermore, it emphases on numerous sources through which persons can obtainentrepreneurial information and abilities and strengthening special effects of each learning source in other which is frequently over looked in entrepreneur learning (Holcombet al. 2009). Additionally, the model stresses on the character of personalities inmanaging and make over the collected knowledge to improve entrepreneur leadership capabilities with considering consideration as one of the essential elements of entrepreneur leadership improvement and developments.

Entrepreneur-ship coaches may also improve entrepreneur leadershipabilities of university students as view point entrepreneur leaders byengagingample and integrated method to designing and developing entrepreneurship learning, education and training programs. The programs should involve students in different entrepreneur leader-ship learning tasks and opportunities where they obtain theknowledge, information, competencies, abilities and capabilities for successful leading entrepreneurial activities.

Precisely, they may find emerging their abilities and capabilities of learning with experience, societal interaction as well as communication and mainly observation as perceptivein their entrepreneur leader-ship development and enlargement and to increase the probability of theirsuccess and achievement in leading entrepreneur activities and actions. More prominently, the model may helpentrepreneur leaders to recognize and highlight the ignoredfeatures of their learning that hamperstheir leader-ship learning (Kempster2009).

Exactly, entrepreneurship coaches can develop and design specific entrepreneur leadershipprograms, packages and ability based syllabuses based on each and every feature ofentrepreneur leadership education and learning. In conclusion, if based on the model,entrepreneur leader-ship development and enlargement occurs through dynamic instrumentof experience, observation, social interaction, communication, and reflection and more significanceshould be positioned on developing and enlargements the capabilities and abilities of entrepreneur leaders in learningfrom a different kind of variety of learning possibilities and opportunities.

Though, so long as students with asteadiness of all these characteristics of entrepreneur leadership learning is one morechallenge and task that entrepreneur-ship coaches need to face. Presently, there happen somecomponents of entrepreneur learning and education in entrepreneur-ship education, training and learningprograms that may grow and develop the basic entrepreneur leadership qualities in students (Okudanand Rzasa 2006), while presenting a combination of all various aspects ofentrepreneur leader-ship learning seems to extra effectively grow and develop the exact abilities that future entrepreneur leaders obtain to successfully handle and leadentrepreneurial venturing. Furthermore, entrepreneur-ship students can keep in mind and consider eachof the various aspects of entrepreneur leadership educationand learning as significant inlearning abilities and capabilities required for leading their further entrepreneur venturingand involve in various entrepreneurial learning opportunities to grow, develop and enlargement of theirentrepreneurial leadership competencies andabilities.

The projected model for entrepreneurial leader-ship learning, enlargement and development hasmany limitations for entrepreneur-ship researchers. First, the model offers aresearch moving stone for exploring entrepreneurial leader-ship learning, grow, enlargement anddevelopment. Furthermore, entrepreneur-ship researchers may take in all possibilities ofentrepreneurial learning in testing and examining entrepreneurial leader-ship development and enlargement.Moreover, the model provides a wellunderstanding of entrepreneurleader-ship learning can be the first step and milestone in developing a theory forentrepreneur leader-ship development. Finally, entrepreneur-ship researchers mayconsider various aspects of entrepreneur 
leader-ship development in assessingthe effectiveness of entrepreneur-ship education and learning programs in growing and developing students'capabilities, competencies of leading entrepreneurial actions and activities.

Even though the model may have significant limitations for entrepreneurleadership practice, education, learning and research, it needs experiential and empirical evidence to support itsdependability, reliability and applicability in growing and developing entrepreneur leader-ship competencies and abilities ofuniversity students, present entrepreneur and entrepreneurial leaders in organizations. The effective-ness of the model in growing and developing entrepreneur leadershipcapabilities and competencies are also needs to be tested in various perspective and with original data to assessif entrepreneur leadership development is a contextual and culturallybased and dependent concept. Exactly, the model needs to be observingthe students withvarious cultural and educational backgrounds to decide and examine if demographicaspects affect the enlargement and development of the entrepreneur leadership abilities and competencies ofthe students.

\section{Future Research Indications}

Future researches can observe and examine how this variety of education and learningopportunities and tasks helps students to grow and develop their entrepreneur leadership abilities, capabilities and competencies and how to deliver a combination of all these characteristics of entrepreneurleadership leaning, education, growing and development. Research work can also be commenced to assess and evaluatewhich aspects of entrepreneur leadership learning has more powerfuland significance impacts ondeveloping and growing the students' entrepreneurial leadership abilities and capabilities, which entrepreneurial leadership abilities can be knowledgeable, learn, grow and developed through each of these entrepreneur learningopportunities (Gupta et al. 2004).

\section{References}

[1]. Anna, A. L., Chandler, G. N., Jansen, E. \& Mero, N. P. (2000) Women Business Owners in Traditional and Non- traditional Industri es, Journal of Business Venturing 15, 279 - 303

[2]. Baron, R.A., and M.D. Ensley. 2006. Opportunity recognition as the detection of meaningfulpatterns: Evidence from the comparison of novice and experienced entrepreneurs.Management Science52, no. 9: 1331-44.

[3]. Chen, M.-H. 2007. Entrepreneurial leadership and new ventures: Creativity in entrepreneurialteams. Creativity and Innovation Management 16, no. 3: 239-49.

[4]. Cogliser, C.C., and K.H. Brigham. 2004. The intersection of leadership and entrepreneurship:Mutual lessons to be learned.The Leadership Quarterly15: 771-99.

[5]. Cope, J. 2003. Entrepreneurial learning and critical reflection: Discontinuous events as triggersfor 'higher-level' learning. Management Learning34, no. 4: 429-50.

[6]. Cope, J. 2005. Toward a dynamic learning perspective of ntrepreneurship.EntrepreneurshipTheory and Practice29, no. 4: 373-97.

[7]. Cope, J., and G. Watts. 2000. Learning by doing: An exploration of experience, criticalincidents and reflection in entrepreneurial learning. International Journal of Entrepreneur-ship Behaviour and Research6, no. 3: 104-24.

[8]. Corbett, A.C. 2005. Experiential learning within the process of opportunity identification andexploitation.Entrepreneurship Theory and Practice29, no. 4: 398-473.

[9]. Dhliwayo, S. 2008. Experiential learning in entrepreneurship education: A prospective modelfor South African tertiary institutions. EducationpTraining50, no. 4: 329-40.

[10]. D’Intino, R.S., M.G. Goldsby, J.D. Houghton, and C.P. Neck. 2007. Self-leadership: Aprocess for entrepreneurial success.Journal of Leadership and Organizational Studies13,no. 4: 105-20.

[11]. Erikson, T. 2003. Towards a taxonomy of entrepreneurial learning experiences among potentialentrepreneurs.Journal of Small Business and Enterprise Development10, no. 1: 106-12.

[12]. Fayolle, A., and B. Gailly. 2008. From craft to science, Teaching models and learningprocesses in entrepreneurship education.Journal of European Industrial Training32, no. 7:569-93.

[13]. Fernald, L.W., G.T. Solomon, and A. Tarabishy. 2005. A new paradigm: Entrepreneurialleadership. Southern Business Review30, no. 2: $1-10$.

[14]. Frey, R.S. 2010. Leader self-efficacy and resource allocation decisions: A study of smallbusiness contractors in the federal marketspace.USASBE Proceedings, 781-810.

[15]. Fiet, J.O. 2000. The pedagogical side of entrepreneurship theory.Journal of Business Venturing16: 101-17.

[16]. Fuchs, K., A. Werner, and F. Wallau. 2008. Entrepreneurship education in Germany andSweden: What role do different school systems play?Journal of Small Business andEnterprise Development15, no. 2: 365-81.

[17]. Fuller, J.B., and L.E. Marler. 2009. Change driven by nature: A meta-analytic review of theproactive personality literature.Journal of Vocational Behaviour75: 329-45.

[18]. Gupta, V., I.C. MacMillan, and G. Surie. 2004. Entrepreneurial leadership: Developing andmeasuring a cross-cultural construct.Journal of Business Venturing19: 241-60.

[19]. Hannah, S.T., B.J. Avolio, F. Luthans, and P.D. Harms. 2008. Leadership efficacy: Reviewand future directions.The Leadership Quarterly19: 669-92.

[20]. Hannon, P.D. 2006. Teaching pigeons to dance: Sense and meaning in entrepreneurshipeducation.EducationpTraining48, no. 5: 296-308.

[21]. Harris, M.L., and S.G. Gibson. 2008. Examining the entrepreneurial attitudes of US businessstudents.EducationpTraining50, no. 7: 568-81.

[22]. Harrison, R.T., and C.M. Leitch. 2005. Entrepreneurial learning: Researching the interfacebetween learning and the entrepreneurial context.Entrepreneurship Theory and Practice29, no. 4: 351-71.

[23]. Heinonen, J. 2007. An entrepreneurial-directed approach to teaching corporate entrepreneur-ship at university level.EducationpTraining49, no. 4: 310-24. 
[24]. Heinonen, J., and S.-A. Poikkijoki. 2006. An entrepreneurial-directed approach toentrepreneurship education: mission impossible? Journal of Management Development25, no. 1: 80-94.

[25]. Henry, C., F. Hill, and C. Leitch. 2005. Entrepreneurship education and training: canentrepreneurship be taught?EducationpTraining47, no. 2: 98-111.

[26]. Holcomb, T.R., R.D. Ireland, R.M. Holmes, and M.A. Hitt. 2009. Architecture ofentrepreneurial learning: Exploring the link among heuristics, knowledge, and action.Entrepreneurship Theory and Practice33, no. 1: 167-92.

[27]. Holt, D.T., M.W. Rutherford, and G.R. Clohessy. 2007. Corporate entrepreneurship: anempirical look at individual characteristics, context, and process.Journal of Leadershipand Organizational Studies13, no. 4: 40-54.

[28]. Kempster, S.J. 2006. Leadership learning through lived experience: A process of apprentice-ship?Journal of Management and Organization129, no. 1: 4-22.

[29]. Kempster, S.J. 2009. Observing the invisible: Examining the role of observational learning inthe development of leadership practice. Journal of Management Development28, no. 5:439-56.

[30]. Kempster, S.J., and J. Cope. 2010. Learning to lead in the entrepreneurial context.Journal ofEntrepreneurial behaviour and Research16, no. 6: 5-34.

[31]. Kickul, J., and L.K. Gundry. 2002. Prospecting for strategic advantage: The proactiveentrepreneurial personality and small firm innovation. Journal of Small BusinessManagement40: 85-97.

[32]. Ko, S., and J.E. Butler. 2007. Creativity: A key link to entrepreneurial behaviour.BusinessHorizons50: 365-72.

[33]. Kolb, D.A. 1984.Experiential learning: Experience as the source of learning and development.New Jersey: Prentice-Hall.

[34]. Kuratko, D.F. 2005. The emergence of entrepreneurship education: development, trends, andchallenges.Entrepreneurship Theory and Practice29, no. 5: 577-97.

[35]. Kuratko, D.F. 2007. Entrepreneurial leadership in the 21st century.Journal of Leadership andOrganizational Studies13, no. 4: 1-11.

[36]. Kuratko, D.F., and J.S. Hornsby. 1999. Corporate entrepreneurial leadership for the $21^{\text {st }}$ century.Journal of Leadership and Organizational Studies5, no. 27: 27-39.

[37]. Kuratko, D.F., J.S. Hornsby, and M.G. Goldsby. 2007. The relationship of stakeholdersalience, organizational posture, and entrepreneurial intensity to corporate entrepreneur-ship.Journal of Leadership and Organizational Studies13, no. 4: 56-72.

[38]. Lans, T., and M. Mulder Competence, empirical insights from a small-business perspective.Decowe Conference: Ljubljana, Slovenia, 24-25, September 2009.

[39]. Lans, T., W. Hulsink, H. Baert, and M. Mulder. 2008. Entrepreneurship education andtraining in a small business context: Insights from the competence-based approach.Journal of Enterprising Culture16, no. 4: 363-83.

[40]. Major, D.A., J.E. Turner, and T.D. Fletcher. 2006. Linking proactive personality and the bigfive to motivation to learn and development activity.Journal of Applied Psychology91:927-35.

[41]. Man, T.W.Y., and C.W.M. Yu. 2007. Social interaction and adolescent's learning in enterpriseeducation: An empirical study.EducationpTraining49: 620-33.

[42]. Matlay, H. 2005. Researching entrepreneurship and education. Part 1: What is entrepreneur-ship and does it matter?EducationpTraining47: 665-77.

[43]. Matlay, H. 2006. Researching entrepreneurship and education. Part 2: What is entrepreneur-ship education and does it matter?EducationpTraining48: 704-18.

[44]. Mattare, M. 2008. Teaching entrepreneurship: The case for an entrepreneurial leadershipcourse.USASBE Proceedings, $78-93$.

[45]. Minniti, M., and W. Bygrave. 2001. A dynamic model of entrepreneurial learning.Entrepreneurship Theory and Practice25, no. 3: 5-16.

[46]. Mueller, S.L., and A.S. Thomas. 2000. Culture and entrepreneurial potential: A nine countrystudy of locus of control and innovativeness.Journal of Business Venturing16: 51-75.

[47]. Murali, S., A. Mohani, and Y. Yuzliani. 2009. Impact of personal qualities and management skills of entrepreneurs on venture performance in Malaysia: Opportunity recognition skillsas a mediating factor.Technovation29: 798-805.

[48]. Murphy, S.E., and E.A. Ensher. 2008. A qualitative analysis of charismatic leadership increative teams: The case of television directors. The Leadership Quarterly19: 335-52.

[49]. Okudan, G.E., and S.E. Rzasa. 2006. A project-based approach to entrepreneurial leadershipeducation.Technovation26: 195-210.

[50]. Peterman, N.E., and J. Kennedy. 2003. Enterprise education: Influencing students'perceptions of entrepreneurship.Entrepreneurship: Theory and Practice28, no. 2: 129-45.

[51]. Pittaway, L., and J. Cope. 2007. Simulating entrepreneurial learning: Integrating xperientialand collaborative approaches to learning.Management Learning38, no. 2: 211-33.

[52]. Plaschka, G.R., and H.P. Welsch. 1990. Emerging structures in entrepreneurship education:Curricular designs and strategies.Entrepreneurship Theory and Practice14, no. 3: 55-70.

[53]. Politis, D. 2005. The process of entrepreneurial learning: A conceptual framework.Entrepreneurship Theory and Practice29, no. 3: $399-424$.

[54]. Rae, D. 2000. Understanding entrepreneurial learning: A question of how?InternationalJournal of Entrepreneurial Behaviour and Research6, no. 3: 145-59.

[55]. Rae, D. 2006. Entrepreneurial learning: A conceptual framework for technology-basedenterprise.Technology Analysis and Strategic Management18, no. 1:39-56.

[56]. Rae, D. 2007. Connecting enterprise and graduate employability: Challenges to the highereducation culture and curriculum?EducationpTraining49: 605-19.

[57]. Rae, D., and M. Carswell. 2000. Using a life-story approach in entrepreneurial learning: Thedevelopment of a conceptual model and its implications in the design of learningexperiences.EducationpTraining42: 220-7.

[58]. Robinson, D.A., M. Goleby, and N. Hosgood. 2006. Entrepreneurship as a values andleadership paradigm. http://epublications.bond.edu.au/ business pubs/10 (accessed July12, 2009).

[59]. Smith, A.J., L.A. Collins, and P.D. Hannon. 2006. Embedding new entrepreneurshipprogrammes in UK higher education institutions, challenges and considerations.EducationpTraining48: 555-67.

[60]. Souitaris, V., S. Zerbinati, and A. Al-Laham. 2007. Do entrepreneurship programmes raiseentrepreneurial intention of science and engineering students? The effect of learning,inspiration and resources. Journal of Business Venturing22: 566-91.

[61]. Surie, G., and A. Ashley. 2008. Integrating pragmatism and ethics in entrepreneurialleadership for sustainable value creation. Journal of Business Ethics81: 235-46.

[62]. Swiercz, P.M., and S.R. Lydon. 2002. Entrepreneurial leadership in high-tech firms: A fieldstudy.Leadership and Organization Development Journal23, no. 7: 380-6. 
[63]. Tan, S.S., and F.C.K. Ng. 2006. A problem-based learning approach to entrepreneurshipeducation.EducationpTraining48, no. 6: $416-28$.

[64]. Vecchio, R.P. 2003. Entrepreneurship and leadership: Common trends and common threads.Human Resource Management Review13: 303-27.

[65]. Yang, C.-W. 2008. The relationships among leadership styles, entrepreneurial orientation, andbusiness performance.Managing Global Transitions6, no. 3: 257-75.

[66]. Young, J.E., and D.L. Sexton. 2003. What makes entrepreneurs learn and how do they do it?Journal of Entrepreneurship12: 155-82.

[67]. Yukl, G. 1998.Leadership in organizations. 4th ed. Upper Saddle River NJ: Prentice Hall.

[68]. Zampetakis, L.A. 2008. The role of creativity and proactivity on perceived entrepreneurialdesirability.Thinking Skills and Creativity3: 154-62.

[69]. Zhao, H., S.E. Seibert, and G.E. Hills. 2005. The mediating role of self-efficacy in thedevelopment of entrepreneurial intentions.Journal of Applied Psychology90, no. 6: 265-72. 